\title{
Non-compliance to treatment among type 2 diabetic men in Mosul: A case-control study
}

\author{
Waleed G.A. Al-Taee \\ Department of Community Medicine, College of Medicine, University of Mosul.
}

(Ann. Coll. Med. Mosul 2009; 35(2): 147-153).

Received: $24^{\text {th }}$ May 2009; Accepted: $10^{\text {th }}$ Feb 2010.

\begin{abstract}
Context: Non-compliance to treatment among diabetic patients is a world-wide problem and its underlying risk factors can be the subject of many studies in different localities.

Objective: To identify risk factors for non-compliance to treatment plan among type 2 diabetic men attending Al-Wafaa Center for diabetes in Mosul City.

Methods: A case-control study design has been adopted. A special questionnaire form has been prepared and filled in by the investigator for each patient (case and control) through direct interview with patients.

Results: Study results revealed a significant association between non-compliance and socioeconomic strata, duration of disease $>10$ years, number of tablets $>2$ daily, frequency of taking medication $>2$, poor patient satisfaction about health personnel, body mass index $>30$ and sedentary life style activities.

On the other hand, an inverse association was found between non-compliance and urban place of residence, marriage, $1^{0}$ and $2^{0}$ school level of education, taking medical treatment without herbals and type A personality.

Conclusion: The study concluded that health care professionals are in need to identify risky patients for non-compliance and recommends to use the counseling approach of communication before applying any individual patient management plan characteristics.
\end{abstract}

Keywords: Type 2 diabetes, compliance, treatment.

الخلاصة

خلقية إجراء الاراسة: يعتبر عدم التزام مرضى السكري بالعلاج من المعضلات العالمية وإن دراسة عوامل الخطورة

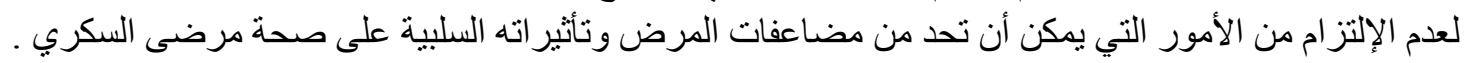
هدف الدراسة: التعرف على عو امل الخطورة لعدم الإلتز ام بخطة العلاج لدى المرضى المصابين بداء السكر - النوع الثاني

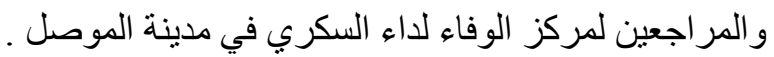
طريقة إجراء الدراسة: تم اختيار تصميم در اسة العينة و الثاهد حيث أعد الباحث نموذج خاص لجمع البيانات تم ملاء ملاه من

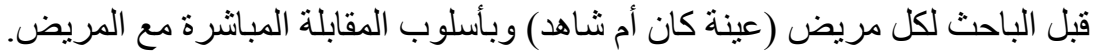
نتائج الدراسة: أظهرت نتائج الدر اسة وجود علاقة إحصائية معنوية بين عدم الالتز ام بالعلاج وتدني المستوى الإقتصادي

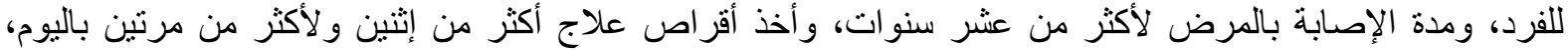

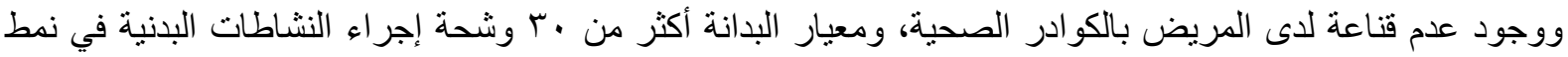

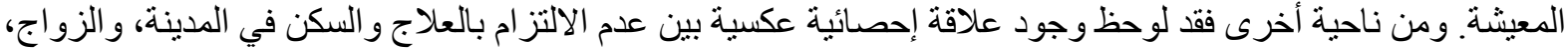
ومستوى التعليم الابتدائي والثانوي، وأخذ العلاج الطبي بدون أعشاب ونمط الثخصية. 


$$
\begin{aligned}
& \text { استنتاجات الدراسة: هناك حاجة ملحة لمقدمي الرعاية الصحية في التحديد المسبق للمرضى المعرضين لحالة عدم الالتزام }
\end{aligned}
$$

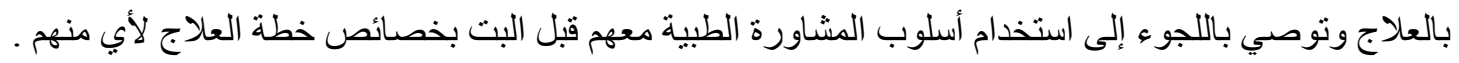

$\mathrm{T}$ ype 2 diabetes is a complex metabolic disorder of heterogeneous etiology with social, behavioral, and environmental risk factors unmasking the effects of susceptibility. $(1,2)$ It is the most common clinical form of diabetes worldwide; it accounts for about 90$95 \%$ of all cases of diabetes globally ${ }^{(3)}$. The disease is typically treated with diet regimen, life style changes and oral medication ${ }^{(1,2)}$. There is strong evidence that vigorous treatment can decrease morbidity and mortality by decreasing its chronic complications $^{(4)}$.

Patient's non-compliance to treatment plan influences glycemic control ${ }^{(5)}$. A wide variety of studies demonstrate that patients who fail to adhere to the prescribed clinical regimens have very poor outcomes ${ }^{(6,7)}$. The likelihood of recurrent diabetic crises is related in part to patient non- compliance ${ }^{(6,8,9)}$.

In diabetes care, non-compliance may represent an important component of unnecessary health care cost, especially hospital costs. Thus the development of effective and efficient methods to assess the possible contributors to non-compliance in the out-patient setting appears very desirable $(10,11)$

Non compliant type 2 diabetics refer to those patients who intentionally don't follow what they are told about their illness and they don't follow the recommendations including self management behaviors, changes in lifestyle and adherence to medication ${ }^{(12-15)}$. In other words, non-compliant diabetics disobey the advice of their health care provider ${ }^{(16) .}$

The concept of non-compliance not only assumes a negative attitude toward patients, but also places patients in a passive unequal role in relationship to their care provider. Noncompliance is attributed to personal qualities of patients, such as forgetfulness, lack of will power or discipline, or low level of education ${ }^{(17)}$. The quality of provider-patient relationship also influences compliance. ${ }^{(18-20)}$
Lower regimen adherence can be expected when a health condition is chronic, when the course of symptoms varies or when symptoms are not apparent, when a regimen is more complex, and when a treatment regimen requires lifestyle changes ${ }^{(21,22)}$.

Study aim is to identify risk factors for noncompliance to treatment plan among type 2 diabetic men in Mosul.

\section{Subjects and Methods}

To start with, and in regard to ethical issue, a seminar about the research protocol was conducted at the Department of Community Medicine. Also official permissions were obtained from Al-Wafaa Center for diabetes and Nineveh Health Directorate. Al-Wafaa Center for diabetes is the only specialized center in Mosul that deals with the management of diabetic patients. It offers services to all diabetics in Mosul city. It has been established in 1999. A written consent form has been prepared to be signed in by each patient agreed to be involved in the study. To achieve the aim of the present study a case control study design has been adopted.

Study subjects are 310 male patients with type 2 diabetes (150 cases and 160 controls) within the age $\geq 18$ years. All were taken randomly from Al-Wafaa center attendants.

Cases were considered as non compliant patient whose age was $\geq 18$ years with type 2 diabetes for more than one year, and has at least three of the following inclusion criteria:

1. Doesn't follow a proper dietary regimen .

2. Doesn't take medicine regularly.

3. Doesn't adopt measures to control his bodyweight.

4. Doesn't conduct regular physical activity.

While controls included compliant patients whose age was $\geq 18$ years, with type 2 diabetes for more than one year, and has at least three of the following inclusion criteria including criterion number two: 
1. Follows proper dietary regimen.

2. Takes medication regularly.

3. Follows proper weight control measures.

4 . Adopts regular physical activity.

All the above mentioned inclusion criteria for cases and control have been put by the investigator and through a seminar which was conducted at Community Medicine Department .

Data collection tool was a special questionnaire form prepared by the investigator through utilizing the available related literatures and taking in consideration the idea of the specialized physicians at the Department of Community Medicine and AlWafaa Center for diabetes. All the questionnaire items were reviewed by community medicine teaching staff to consider its validity and reliability which were $85 \%$. Economic status has been determined high, middle or low according to the type of occupation, presence or absence of private house ownership and car ownership.

Statistical analysis was done after tabulation of collected data; $P$ value and odds ratio were calculated, looking for any statistical association between non compliance and other factors.

\section{Results}

Study results revealed that $42 \%$ of study population are within the age group 41-50 years, more than $80 \%$ of them are from urban regions, married and with $1^{\circ}$ and $2^{0}$ school education level. No significant difference was obtained between compliants and noncompliants in regard to age, marital status and level of education. However, a weak significant difference between compliants and noncompliants has been found for place of residence $(p=0.048)$ while socio-economic strata was significantly differs $(p=0.000)$.

Table 2 shows a significant association between non-compliance and duration of disease more than 10 years. A diabetic who has the disease since more than 10 years is almost twenty times not adherent to the treatment plan as shown from the significant values of $p$, odd ratio and $95 \%$ C.I. $(p=0.000$, $\mathrm{OR}=18.4,95 \%$ C.I. $=10.28-33.04)$.

In regard to management plan characteristics, the results of the study reveals a highly significant, association between noncompliance and number of tablets $>2$ and daily frequency of drugs administration $>2$ with $P$ value of 0.000 and $O R$ of 21.5 and 31.2 respectively (Table 3 ).

Table (1): Socio-demographic characteristics of study population.

\begin{tabular}{|c|c|c|c|c|c|c|}
\hline \multirow{2}{*}{\multicolumn{2}{|c|}{ Socio-demographic parameter }} & \multicolumn{2}{|c|}{$\begin{array}{c}\text { non-compliants } \\
n=150\end{array}$} & \multicolumn{2}{|c|}{$\begin{array}{c}\text { compliants } \\
n=160\end{array}$} & \multirow[t]{2}{*}{ P-Value } \\
\hline & & No. & $\%$ & No. & $\%$ & \\
\hline \multirow{4}{*}{$\begin{array}{l}\text { Age group } \\
\text { (in years) }\end{array}$} & $<30$ & 29 & 19.3 & 31 & 19.4 & \\
\hline & $30-$ & 41 & 27.3 & 46 & 28.8 & \\
\hline & $40-$ & 63 & 42.0 & 67 & 41.9 & \\
\hline & $\geq 50$ & 17 & 11.3 & 16 & 10.0 & \\
\hline \multicolumn{2}{|l|}{ Mean $\pm S D$} & \multicolumn{2}{|c|}{$39.53 \pm 9.31$} & \multicolumn{2}{|c|}{$39.25 \pm 9.15$} & $0.790^{*}$ \\
\hline \multirow{2}{*}{ Place of residence } & Urban & 127 & 84.7 & 147 & 91.9 & \multirow{2}{*}{$0.048^{* *}$} \\
\hline & Rural & 23 & 15.3 & 13 & 8.1 & \\
\hline \multirow{3}{*}{ Marital status } & Single & 13 & 8.7 & 7 & 4.4 & \multirow{3}{*}{$0.105^{\star *}$} \\
\hline & Married & 130 & 86.7 & 150 & 93.8 & \\
\hline & Others & 7 & 4.7 & 3 & 1.9 & \\
\hline \multirow{3}{*}{ Level of education } & Illiterate & 6 & 4.0 & 3 & 1.9 & \multirow{3}{*}{$0.510^{* *}$} \\
\hline & $1^{0}$ and $2^{0}$ school & 120 & 80.0 & 133 & 83.1 & \\
\hline & University & 24 & 16.0 & 24 & 15.0 & \\
\hline \multirow{3}{*}{$\begin{array}{l}\text { Socio-economic } \\
\text { strata }\end{array}$} & High & 7 & 4.7 & 37 & 23.1 & \multirow{3}{*}{$0.000^{* *}$} \\
\hline & Middle & 70 & 46.7 & 80 & 50.0 & \\
\hline & Low & 73 & 48.7 & 43 & 26.9 & \\
\hline
\end{tabular}

*t-test was used

** chi square was used 
Table (2): Association of non- compliance and duration of the disease

\begin{tabular}{|l|c|c|c|c|c|c|c|}
\hline \multirow{2}{*}{$\begin{array}{c}\text { Duration of disease } \\
\text { (in years) }\end{array}$} & \multicolumn{2}{|c|}{$\begin{array}{c}\text { non-compliants } \\
\mathrm{n}=150\end{array}$} & \multicolumn{2}{c|}{$\begin{array}{c}\text { Compliants } \\
\mathrm{n}=160\end{array}$} & \multirow{2}{*}{$\begin{array}{c}\text { Odds ratio } \\
\%\end{array}$} & 95 \% C.I & P-value \\
\cline { 2 - 5 } & No. & $\%$ & No. & $\%$ & & & \\
\hline$>10$ & 129 & 86.0 & 40 & 25.0 & 18.4 & $10.28-33.04$ & 0.000 \\
\hline$\leq 10$ & 21 & 14.0 & 120 & 75.0 & & \\
\hline
\end{tabular}

Table (3): Association between management plan parameters and non-compliance.

\begin{tabular}{|c|c|c|c|c|c|c|c|c|}
\hline \multicolumn{2}{|c|}{ Management plan characteristics } & \multicolumn{2}{|c|}{$\begin{array}{c}\text { non- } \\
\text { compliants } \\
n=150\end{array}$} & \multicolumn{2}{|c|}{$\begin{array}{l}\text { compliants } \\
n=160\end{array}$} & \multirow[t]{2}{*}{$\begin{array}{l}\text { Odds } \\
\text { ratio }\end{array}$} & \multirow[t]{2}{*}{95 \% C.I } & \multirow[t]{2}{*}{ P-Value } \\
\hline & & No. & $\%$ & No. & $\%$ & & & \\
\hline \multirow{2}{*}{$\begin{array}{l}\text { Method of } \\
\text { hyperglycemic } \\
\text { control }\end{array}$} & $\begin{array}{l}\text { Medical } \\
\text { without } \\
\text { herbals }\end{array}$ & 21 & 14.0 & 157 & 98.0 & \multirow[t]{2}{*}{0.0} & \multirow[t]{2}{*}{$0.001-0.011$} & \multirow[t]{2}{*}{0.000} \\
\hline & $\begin{array}{l}\text { Medical with } \\
\text { herbals }\end{array}$ & 129 & 86.0 & 3 & 1.9 & & & \\
\hline \multirow{2}{*}{ Number of tablets } & $>2$ & 124 & 82.7 & 29 & 18.1 & \multirow{2}{*}{21.5} & \multirow{2}{*}{$12.020-38.615$} & \multirow{2}{*}{0.000} \\
\hline & $\leq 2$ & 26 & 17.3 & 131 & 81.9 & & & \\
\hline \multirow{2}{*}{$\begin{array}{l}\text { Daily frequency in } \\
\text { taking medication }\end{array}$} & $>2$ & 127 & 84.7 & 24 & 15.0 & \multirow{2}{*}{31.2} & \multirow{2}{*}{$16.816-58.221$} & \multirow{2}{*}{0.000} \\
\hline & $1-2$ & 23 & 15.3 & 136 & 85.0 & & & \\
\hline \multirow{2}{*}{$\begin{array}{l}\text { Way of taking } \\
\text { therapy }\end{array}$} & Proper & 40 & 26.7 & 147 & 91.9 & \multirow{2}{*}{0.0} & \multirow{2}{*}{$0.016-0.063$} & \multirow{2}{*}{0.000} \\
\hline & Improper & 110 & 73.3 & 13 & 8.1 & & & \\
\hline
\end{tabular}

Regarding personal characteristics of patients, table 4 shows a significant association between non-compliance and poor patient's satisfaction about health personnel, body mass index $>30$ and sedentary life style activity $(p=0.000$ and OR of $5.3,20.2$, and 10.6 respectively).

Table (4): Association between health status variables and non-compliance.

\begin{tabular}{|c|c|c|c|c|c|c|c|c|}
\hline \multirow{2}{*}{\multicolumn{2}{|c|}{ Personal characteristic }} & \multicolumn{2}{|c|}{$\begin{array}{c}\text { non- } \\
\text { compliants } \\
n=150\end{array}$} & \multicolumn{2}{|c|}{$\begin{array}{l}\text { compliants } \\
n=160\end{array}$} & \multirow[t]{2}{*}{$\begin{array}{l}\text { Odds } \\
\text { ratio }\end{array}$} & \multirow[t]{2}{*}{$95 \%$ C.I } & \multirow[t]{2}{*}{ P-Value } \\
\hline & & No. & $\%$ & No. & $\%$ & & & \\
\hline \multirow{2}{*}{$\begin{array}{l}\text { Patient's } \\
\text { satisfaction about } \\
\text { health personnel }\end{array}$} & Dissatisfied & 83 & 55.3 & 30 & 18.8 & \multirow{2}{*}{5.3} & \multirow{2}{*}{$3.220-8.949$} & \multirow{2}{*}{0.000} \\
\hline & Satisfied & 67 & 44.7 & 130 & 81.2 & & & \\
\hline \multirow{2}{*}{$\begin{array}{l}\text { Personal state of } \\
\text { activity }\end{array}$} & $\begin{array}{l}\text { Sedentary } \\
\text { lifestyle }\end{array}$ & 117 & 78.0 & 40 & 25.0 & \multirow{2}{*}{10.6} & \multirow{2}{*}{$6.282-18.009$} & \multirow{2}{*}{0.000} \\
\hline & $\begin{array}{l}\text { Physically } \\
\text { active person }\end{array}$ & 33 & 22.0 & 120 & 75.0 & & & \\
\hline \multirow{3}{*}{ Body mass index } & $<25$ & 7 & 4.7 & 31 & 19.4 & 0.2 & $0.087-0.479$ & 0.000 \\
\hline & $25-29.9$ & 17 & 11.3 & 96 & 60.0 & 0.0 & $0.047-0.155$ & 0.000 \\
\hline & $\geq 30$ & 126 & 84.0 & 33 & 20.6 & 20.2 & $11.305-36.111$ & 0.000 \\
\hline \multirow{2}{*}{$\begin{array}{l}\text { Type of } \\
\text { personality }\end{array}$} & A & 29 & 19.3 & 156 & 97.5 & \multirow{2}{*}{0.0} & \multirow{2}{*}{$0.002-0.018$} & \multirow{2}{*}{0.000} \\
\hline & B & 121 & 80.7 & 4 & 2.5 & & & \\
\hline
\end{tabular}




\section{Discussion}

A case-control study design was adopted. The advantages of such design are better availability of cases, it needs less time and economically less expensive ${ }^{(23)}$. On the other hand, bias could occur in selection of cases and/or controls. In addition no actual causation can be proved; only associations between disease and risk factors of interest can be detected $^{(24)}$. Regarding limitations of the present study, as it was conducted upon patients attending Al-Wafaa Center for diabetes, the study subjects might not represent all diabetic patients in Mosul.

About $81 \%$ of cases and controls were from the age groups above 30 years. Such result could be explained through the fact that type 2 diabetes is typically an adult onset disease. No significant difference was obtained between cases and controls in regard to age, marital status and level of education. Such result can reflect the proper selection of cases and controls.

More than $80 \%$ of cases and controls were from urban places. Data from developing countries show that diabetes is more prevalent among urban population. Urbanization and high socio economic status are associated with the development of diabetes in susceptible people as they adopt western life style behavior which includes consumption of unhealthy diet ${ }^{(25)}$.

Around $80 \%$ of study population were within the educational level of $1^{\circ}$ and $2^{0}$ school. Such result can express the level of education among such group in Mosul population ${ }^{(25)}$.

From other point of view, ( $>10$ years) duration of disease was found to carry higher levels of non-compliance. Similar to the findings of a study conducted in Canada: $62 \%$ of people with diabetes for $\geq 15$ years were non-compliant ${ }^{(26)}$.

In regard to management plan characteristics, highly significant association was found with ( $>2$ number of tablets) and frequency of administration. Perhaps forgetfulness in taking drug is the problem. As the number of pills increases and number of times pills must be taken each day rises, compliance fails ${ }^{(27)}$. Patients who took the drug once a day did a much better job at sticking with their plan. They took correct number of doses on more days, and they miss doses often, less than those taking the drug twice aday. Drugs taken once a-day may have important advantages over drugs taken twice a-day in treatment of type 2 diabetes $^{(25,28)}$.

A significant result was found between noncompliance and poor patient satisfaction about health personnel. Making patient satisfied with health personnel is one of the key elements to success in achieving good glycemic control $(12,22,29)$. Negative view of patients toward their doctor and poor provider communication have lower compliance rates to oral medications and self monitoring of blood glucose $e^{(33)}$.

The present study revealed that $84 \%$ of cases have BMI $>30$ against $20.6 \%$ of controls. Such high rate of obesity among non compliant patients goes with the finding of ALChetachi ${ }^{(31)}$ study which demonstrated that $88.3 \%$ of diabetic patients were over weight and obese. Similar finding was documented by Fadhil et al ${ }^{(32)}$ in 2003.

Study results revealed that $78 \%$ of cases had sedentary life style activities against only $18.8 \%$ of controls. Such result goes with the findings of several studies ${ }^{(25,32,33)}$. Exercise is an important component in the management of diabetes. The amount of regular physical activity plays an important role in maintaining a healthy body weight, and lowering the risk of diabetes ${ }^{(34,35,36)}$.

\section{Conclusion}

Identification of risk factors to non-compliance to treatment is essential, prior to applying any treatment method for diabetic patients in order to overcome the problem of non-compliance.

\section{Recommendations}

Risky diabetic patients for non-compliance need to be identified initially before applying any method of management.

In dealing with diabetic patients, physicians have to choose, when possible, the simplest plan characteristics in regard to number of tablets and daily frequency of administration.

For better patient satisfaction, health care professionals are in need to use the counseling approach of communication with 
diabetic patients rather than the traditionally used consultation approach.

Utilizing the mass media for diabetes related health educational programs can improve patient's knowledge and attitude towards higher compliance rates.

\section{References}

1. American Diabetes Association. Type 2 diabetes in children and adolescents. Diabetes Care 2000; 23(3): 381-389.

2. Nolan JJ. What is type 2 diabetes. Clinical Medicine 2002; 30(1):6-8.

3. Williams G, Pickup JC. Handbook of diabetes $2^{\text {nd }}$ edition. UK: Black Well Publishing 2002; 1132-1145.

4. United Kingdom Prospective Diabetes Study Group. Intensive blood glucose control with sulphonylureas or insulin compared with conventional treatment and risk of complications in patient with type 2 diabetes. Lancet 1998; 352(9131): 837853.

5. Chen HS, Jap TS, Chen RL, Lin HD. A prospective study of glycemic control during holiday time in type 2 diabetic patients. Diabetes care 2004; 27:326-330.

6. Rewers A, Chase HP, Mackenzie T, Walravens $P$, Roback $M$, Rewers M,Hamman RF, Klingensmith G. Predictors of acute complications in children with type 2 diabetes. JAMA 2002; 287: 2511-2518.

7. Laing SP, Jones ME, Swerdolow AJ, Burden AV, Gatling W. Psychosocial and socioeconomic risk factors for premature death in young people with type 2 diabetes. Daibetes Care 2005; 28: 618623.

8. Gill G, Lucas S. Brittle diabetes characterized by recurrent hypoglycaemia. Diabetes Metab 1999; 25:8-11.

9. Skinner TC. Recurrent diabetic ketoacidosis: causes, prevention and management. Horm Res 2002;57:78-80.

10. Kuo YF, Raji MA, Markedes KS, Ray LA, Espino DV, Goodwin JS. Inconsistant use of diabetes medications, diabetes complications and mortality in older Mexican Americans over a 7-year period. Diabetes Care 2003; 26: 3054-3060.
11. Maldonado MR, Chong ER, Oehl MA, Balasubramanyam A. Economic impact of diabetic ketoacidosis in a multiethnic indigent population. Diabetes Care 2003; $26: 1265-1269$.

12. Funnell MM, Anderson RM, Arbor A. The problem with compliance in diabetes. JAMA $2000 ; 284: 1709$.

13. Funnell MM, Anderson RM. Empowerment and self management of diabetes. Clinical diabetes 2004; 22: 123-127.

14. Funnell MM. Lessons learned as a diabetes educator. Diabetes Spectrum 2002;13:69-70.

15. Zandra M, Glen N, Pharm D. Advantages of pharmacist-led diabetes education program. US Farm 2005;11:52-61.

16. Winkler A, Teuscher AU, Mueler B, Deim $P$. Monitoring adherence to prescribed medication in type 2 diabetic patients treated with sulfonylureas. Swiss Med wkly 2002;132:379-385.

17. Delamater AM. Improving patient adherence. Clinical diabetes 2006; 24:7177.

18. Winnick S, Lucas DO, Hartman AL, Toll D. How do you improve compliance. Paediatrics 2005; 115:718-724.

19. Chapman RH, Benner JS, Petrilla AA, Tierce JC, Collins SH, Battleman DS, Schwatrz JS. Predictors of adherence with antihypertensive and lipid-lowering therapy. Arch Intern Med 2005; 165:11471152 .

20. Hunt $M$, Nedal $H$, Larme $A$, Robert $M$. Contrasting Patient and Practitioner perspectives in Type 2 diabetes management. An overview to anthropological approaches to type 2 diabetes. Journal of Nursing Research 2003; 20(6): 665-676.

21. Hill-Briggs F, Gary TL, Bone LR. Medication Adherence and diabetes control in urban African Americans with type 2 diabetes. Health Psychol 2005; 24: 349-357.

22. Alan MD. Improving Patient Adherence. Clinical Diabetes 2006; 24(2):71-77. 
23. Altman DG, Machin D, Bryant T, Gardener MJ. Statistics with Conference. 2 edition. UK : BMJ 2000; 45-73.

24. Greenberg RS, Daniels SR, Flanders WD, Eley JW, Boring JR. Medical Epidemiology, $3^{\text {rd }}$ edition. New York : Mc Graw - Hill 2001; 91-112 .

25. Al-Joobory SA. Risk Factors for NonCompliance among women with Type II Diabetes in Mosul. M.Sc. Thesis. Mosul College of Medicine, University of Mosul, Iraq 2008; 39-41.

26. Diabetics' knowledge and their management behavior. Easter Mediterr Health J 1999; 5 (5): 974-983.

27. Reid I, Harris S. Diabetes in Canada Evaluation, Management and Control of type 2 diabetes. The Canadian Family Practice Setting. Conference 2005.

28. Gebhhart F. Combination Products offer alternative for type 2 diabetes patients. Health System Report 2005.

29. Kardas M. The DIACOM Study: Effect of dosing frequency of oral antidiabetic. Diabetes Obes Metab 2005; 7: 722 -728.

30. Anderson RM, Funnell MM, Burkhart N, Gillard ML, Nwankwo R . Tips for behavior change in diabetes education. Clinical Diabetes 2002; 24: 712 -777.
31. Ciechanowski PS, Katon WJ, Russo JE, Walker EA. The Patient - Provider relationship: Attachment theory and Adherence to treatment in diabetes. Am J psychiatry 2001; $158: 29-35$.

32. Al-Chetachi W . Education Program, Type 2 Diabetics. PhD thesis. College of Medicine - Mosul 2006.

33. Fadhil NN, Tahir KM, Mahmood AT. Diabetes Mellitus: exploration of characteristics and evaluation of management. Ann Coll Med Mosul 2003; 29 (1): $1-7$.

34. Hernandez M, Ronquilla L, Tellez Zenteno JF, Gardano Espinosa J, Gonzatez - Acefez E. Factors associated with therapy non compliance in type 2 diabetes. Patients Salad Publica Mex 2003; 35: 191 -197.

35. Roaeid RB, Kablan A. Profile of diabetes health care at Banghazi Diabetes Center in Libya. Arab Jamahiriya 2007; 13 (1): $168-176$.

36. Kadiki OA, Roaeid RB. Prevalence of diabetes and impaired glucose tolerance in Benghazi Libya. Diabetes and Metabolism 2001; 27 (6) : 647 - 654.

37. American Diabetes Association. Physical activity, exercise and type 2 diabetes. Diabetes Care 2004; 27 (1) : 58 - 62 . 